\title{
The performance of parents of children receiving cow's milk free diets at identification of commercial food products with and without cow's milk
}

\author{
Thabata Koester Weber, ${ }^{1}$ Patrícia da Graça Leite Speridião, ${ }^{2}$ \\ Vera Lucia Sdepanian, ${ }^{3}$ Ulysses Fagundes Neto, ${ }^{4}$ Mauro Batista de Morais ${ }^{5}$
}

\begin{abstract}
Objective: To investigate how well the parents of children on cow's milk free diets perform at recognizing whether or not expressions describe and foods contain cow's milk proteins.

Methods: Interviews were conducted with 24 parents of children on cow's milk and by-products exclusion diets and 23 parents of children with no need for any type of exclusion diet. They were asked if they recognized 12 expressions relating to cow's milk. They were then asked to classify 10 commercial food products in terms of whether or not they contained cow's milk proteins.
\end{abstract}

Results: Terms that included the word milk were more often recognized by both groups of parents. The parents of children on exclusion diets recognized the terms cow's milk protein, traces of milk and milk formulation or preparation most frequently $(p<0.05)$. Less than $25.0 \%$ of those interviewed recognized casein, caseinate, lactalbumin and lactoglobulin. Both groups correctly identified more of the commercial products containing cow's milk than those free from milk. The median number of products containing cow's milk (total = 5) correctly identified by the parents of children on exclusion diets (4.0) was greater than for the control group $(3.0 ; p=0.005)$. Reading at least one label was associated with a greater chance of correctly identifying more than five of the 10 products (odds ratio $=8.0$ ).

Conclusions: Despite having received guidance, the parents of children on exclusion diets were not fully prepared to manage these diets, indicating a need for improvements to the instruction provided when indicating exclusion diets.

J Pediatr (Rio J). 2007;83(5):459-464: Hypersensitivity to milk (cow's milk allergy); diet therapy; parents; knowledge, healthcare attitudes and practices.

\section{Introduction}

Allergy to cow's milk protein is one of the most common adverse reactions of childhood, ${ }^{1}$ especially during the first year of life. ${ }^{2}$ A national epidemiological study found that $77.0 \%$ of suspected food allergies in children involved cow's milk. ${ }^{3}$ In Brazil, in common with what is observed in other countries, the prevalence of suspected allergy to cow's milk protein and by-products is around $5.0 \% .^{3,4}$

The principles of treatment for allergy to cow's milk protein are based on: 1 ) the exclusion of cow's milk proteins from the diet, therefore no cow's milk or by-products; 2) prescription of a new substitute diet that is nutritionally adequate. ${ }^{5-8}$ In view of the high nutritional value of cow's milk and its by-products, exclusion diets must be very well managed in order to supply all of the nutrients necessary for the child's growth and development. ${ }^{2,7}$ The foods that make up the diet free from cow's milk and by-products must be of known composition, in order to avoid the reactions that result from inadvertent consumption of the allergen. ${ }^{9}$ Infants younger than 6 months, will, in general, be given special formula as their only

1. Mestranda. Programa de Pós-graduação, Nutrição, Universidade Federal de São Paulo - Escola Paulista de Medicina (UNIFESP-EPM), São Paulo, SP, Brazil.

2. Doutora. Nutricionista, Gastroenterologista pediátrica, UNIFESP-EPM, São Paulo, SP, Brazil.

3. Doutora. Professora adjunta, Gastroenterologia Pediátrica, UNIFESP-EPM, São Paulo, SP, Brazil.

4. Professor titular, Gastroenterologia Pediátrica, e Reitor, UNIFESP-EPM, São Paulo, SP, Brazil.

5. Livre-docente. Professor associado, Gastroenterologia Pediátrica, UNIFESP-EPM, São Paulo, SP, Brazil.

Suggested citation: Weber TK, Speridião PG, Sdepanian VL, Fagundes Neto U, de Morais MB. The performance of parents of children receiving cow's milk free diets at identification of commercial food products with and without cow's milk. J Pediatr (Rio J). 2007;83(5):459-464.

Manuscript received Mar 30 2007, accepted for publication July 102007.

doi 10.2223/JPED.1697 
food source. In the case of patients whose allergy vehicle is breastmilk, it is the mother who diets. Later, from 6 months on, patients with allergy to cow's milk should also be given complementary foods, which must not contain cow's milk proteins in their composition.

Identification of whether or not foods contain cow's milk depends on the list of ingredients printed on labels and packaging. ${ }^{10}$ Errors in product identification may occur because of incorrect labeling ${ }^{11}$ or because of incorrect interpretation by the consumer. ${ }^{10}$ Some of the terms and expressions commonly used on packaging labels can present a major obstacle to recognizing that cow's milk is in the ingredients of a given product. Very often such terms are not recognized by the majority of consumers. ${ }^{10}$

With the intention of providing the evidence on which to base improvements to the nutritional guidance provided when prescribing exclusion diets of cow's milk and by-products, the objective of this study was to investigate how well the parents of children on cow's milk free diets perform at recognizing whether or not expressions describe and foods contain cow's milk proteins.

\section{Methods}

The study enrolled the parents of children treated at the Pediatric Gastroenterology Department's clinic, at the Escola Paulista de Medicina, Universidade Federal de São Paulo (UNIFESP-EPM), Brazil. The study group comprised 24 parents of children on diets free from cow's milk and by-products. The control group was made up of 23 parents or guardians of children with no need for any type of exclusion diet who were invited to participate at random.

The study was explained to the interviewees in both groups and they then signed free and informed consent forms. The study was approved by the Ethics Committee at the Universidade Federal de São Paulo (UNIFESP-EPM).

Data collection was by means of a structured questionnaire with closed questions, applied in four consecutive stages. The first stage collected personal details on the child's guardian. The second collected data for classification by the Brazilian Economic Classification Questionnaire (Critério de Classificação Econômica Brasil), according to methodology proposed by the Brazilian Advertisers Association (ABA - Associação Brasileira de Anunciantes), the Brazilian Association of Market Research Companies (ABEP - Associação Brasileira de Empresas de Pesquisa), and the Brazilian Association of Market Research Institutes (ABIPEME - Associação Brasileira de Institutos de Pesquisa de Mercado), for economic assessment of Brazilian consumers. ${ }^{12}$ According to this classification, individuals can be assigned to one of five classes (A, B, $C, D$ and $E$ ), with class $A$ indicating the best economic status.

In the third stage, objective questions were asked about any dietary guidance given when the diet excluding cow's milk and by-products was prescribed. Questions covered: the number of times dietary guidance had been provided previously (never, once, twice, three or more times); which professional provided the guidance (physician, nutritionist or both); whether the professional had instructed the exclusion of: 1) cow's milk and by-products or 2) cow's milk, its by-products and other foods; whether the professional had instructed them to read labels (yes or no) and guidance on which words are associated with cow's milk (yes or no). During this stage of the questionnaire, questions were also included on knowledge of expressions related to milk, for both groups. Among the popular terms related to this type of milk were powdered milk, whole milk, skimmed milk and semiskimmed milk. Technical expressions related to cow's milk included: dairy products, traces of milk, cow's milk protein and milk formulation or preparation. The scientific expressions included were casein, caseinate, lactalbumin and lactoglobulin. The interviewee replied yes if they recognized the expression or no if not case negative.

At the end of the questionnaire, it was observed whether or not the interviewee was capable of identifying whether commercial food products were cow's milk free. In this stage, 10 products commonly given to infants, as complementary foods, or to toddlers, were given to the interviewee in their original format, with packaging intact. Five products contained cow's milk or by-products (Delícia ${ }^{\circledR}$ margarine, Actívia ${ }^{\circledR}$, Mucilon ${ }^{\circledR} 5$ flavors cereal, whole milk drink and Bauny ${ }^{\circledR}$ cookies) and five did not (Becel ${ }^{\circledR}$ margarine, Bio Soja ${ }^{\circledR}$ yoghurt, Mucilon ${ }^{\circledR}$ maize cereal, Ades ${ }^{\circledR}$ drink and Adria ${ }^{\circledR}$ cookies). The products were arranged on a table and the parents were asked to distribute the foods into groups, according to their opinion of whether or not they contained cow's milk and by-products: 1 ) a group of foods that contain cow's milk; 2) a group of foods that do not contain cow's milk and; 3) a group of foods about which they were unsure, i.e. the interviewee was not certain whether or not they could identify cow's milk as present or not. While the interviewees were distributing the foods into the three categories, one of the authors (TKW) observed whether or not they read the labels of each of the products.

Once the products were all sorted into groups, the correct and incorrect choices were recorded for each product. When the results of the identification were analyzed, two possibilities were considered: 1) correct, 2) incorrect (errors and doubts).

Considering that similar articles do not exist, the sample size estimation was based on the first 10 results for each group (pilot study). To this end, the variable was defined as the number of correctly classified products out of the total of 10 . It was observed that the difference in number of correct choices between parents of patients on exclusion diets and the controls was 1.58 , with a standard deviation of 1.80 . The calculation was performed using the sample size module of SigmaStat $3.1,{ }^{13}$ and indicated a need for a minimum of 22 
Table 1 - Sex, age, economic class (according to the Brazilian Economic Classification Questionnaire) and previous instruction by a physician and/or nutritionist on how to implement the diet free from cow's milk and by-products

\begin{tabular}{|c|c|c|c|}
\hline & $\begin{array}{c}\text { Study group } \\
(n=24)\end{array}$ & $\begin{array}{l}\text { Control group } \\
\quad(n=23)\end{array}$ & $\mathbf{p}$ \\
\hline Sex (female/male)* & $22 / 2$ & $16 / 7$ & 0.072 \\
\hline Age $(\text { years })^{+}$ & $30.9 \pm 6.8$ & $32.7 \pm 6.8$ & 0.363 \\
\hline Educational level of interviewees ${ }^{\ddagger}$ & & & 0.207 \\
\hline Primary education unfinished & $2(8.3 \%)$ & $0(0.0 \%)$ & \\
\hline Graduated primary school & $3(12.5 \%)$ & $7(30.5 \%)$ & \\
\hline Graduated middle school & $6(25.0 \%)$ & $6(26.0 \%)$ & \\
\hline Graduated secondary school & $12(50.0 \%)$ & $7(30.5 \%)$ & \\
\hline Graduated higher education & $1(4.2 \%)$ & $3(13.0 \%)$ & \\
\hline Brazilian Economic Classification Questionnaire ${ }^{\neq}$ & & & 0.095 \\
\hline Economic class A & $0(0.0 \%)$ & $1(4.4 \%)$ & \\
\hline Economic class B & $6(25.0 \%)$ & $4(17.4 \%)$ & \\
\hline Economic class $\mathrm{C}$ & $10(41.7 \%)$ & $16(69.6 \%)$ & \\
\hline Economic class D & $8(33.3 \%)$ & $2(8.7 \%)$ & \\
\hline Professional instruction on diet free from cow's milk and by-products ${ }^{\ddagger}$ & & & 0.000 \\
\hline Never & $0(0.0 \%)$ & $23(100.0 \%)$ & \\
\hline Once & $7(29.2 \%)$ & $0(0.0 \%)$ & \\
\hline Twice & $2(8.3 \%)$ & $0(0.0 \%)$ & \\
\hline Three times or more & $15(62.5 \%)$ & $0(0.0 \%)$ & \\
\hline
\end{tabular}

\footnotetext{
* Fisher's exact test.

+ Mean and standard deviation, Student's $t$ test.

₹ Chi-square test.
}

individuals in each group. Therefore, the number of individuals in each group was greater than the minimum requirement.

Numerical variables were expressed in the form of means and standard deviations or medians with their 1st and 3rd quartiles. Comparisons between groups were made with either Student's $t$ test or the Mann-Whitney test, depending on the behavior of variables with relation to normal distribution. The Wilcoxon test was used for comparisons within groups. The degree of association between two numerical variables was quantified using Pearson's linear coefficient. Calculations were performed with the aid of SigmaStat 3.1 software. ${ }^{13}$ Categorical variables represented as percentages were tested using chi-square on Epi-Info. ${ }^{14}$ The level of significance was set at $5.0 \%$.

\section{Results}

The study group was made up of 24 individuals ( 22 women and two men), with a mean ( \pm standard deviation) age of $30.9 \pm 6.8$ years. The control group comprised 23 individuals (16 women and seven men), with a mean age of $32.7 \pm 6.8$ years. The interviewees in both groups belonged to a range of economic classes and educational levels. The majority of them said they had graduated secondary school. With relation to economic classification criteria, the majority of individual in both groups belonged to economic class $C$. As can be observed in Table 1, there were no statistically significant differences between the groups in terms of sex, age, educational level or economic class. The majority of the individuals in the study group had been instructed on how to implement the cow's milk and by-products free diet (either at our center or at another service), at three or more previous consultations (with a physician and/or nutritionist). The members of the control group had never received instruction on cow's milk free diets (Table 1). In the study group, $71.0 \%$ of those interviewed had been instructed to exclude cow's milk and by-products, while $29.0 \%$ were instructed to exclude cow's milk, by-products and soy. Of these, $80.0 \%$ reported having been instructed to read product labels, while just $38.0 \%$ described having received instruction on which words are associated with cow's milk.

With relation to knowledge of popular expressions related to cow's milk in the study $(n=24)$ and control $(n=23)$ groups respectively, the following percentages were observed of recognition of the terms whole milk (100.0 and $87.0 \%)$, powdered milk (96.0 and $87.0 \%)$, skimmed milk (96.0 and $97.0 \%$ ) and semi-skimmed milk (88.0 and $70.0 \%$ ), all with $p$ $>0.05$. For the technical expressions, these proportions were: dairy products ( 71.0 and $45.0 \%, \mathrm{p}=0.060)$, cow's milk protein $(71.0$ and $9.0 \%, p=0.001)$, traces of milk (54.0 and $9.0 \%, p=0.001)$ and milk formulation or preparation (42.0 


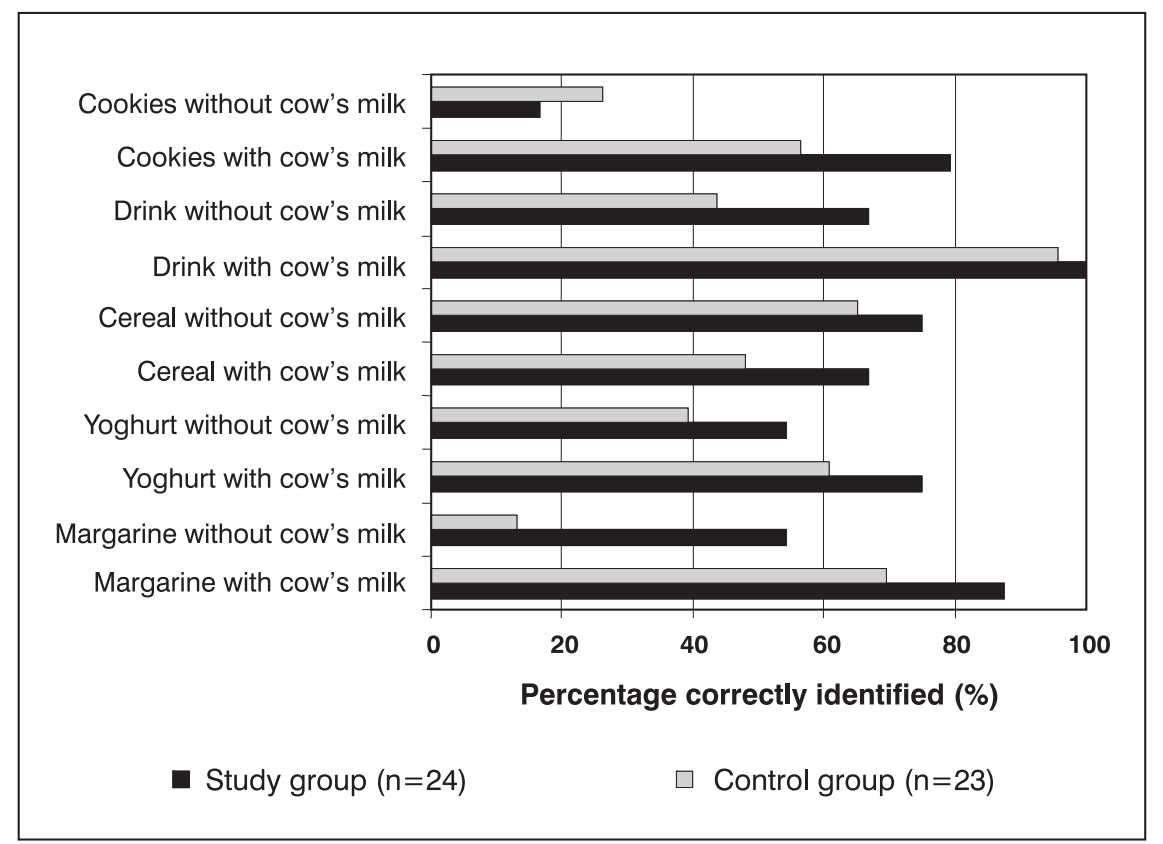

Fisher's exact test: $p>0.05$ for all of the commercial food products, with the exception of margarine without cow's milk $(p=0.005)$.

Figure 1 - Percentage of parents correctly identifying each product as with or without cow's milk in each group, study and control

and $13.0 \%, p=0.03)$. Recognition of the scientific expressions did not exhibit any statistically significant differences $(p$ $>0.05$ ) for casein (25.0 and $4.0 \%$ ), lactalbumin (17.0 and $4.0 \%$ ) or lactoglobulin ( 8.0 and $4.0 \%$ ), whereas, for caseinate $(21.0$ and $0.0 \%, p=0.027)$ the difference did have statistical significance.

In Figure 1 it can be observed that a smaller proportion of the control group correctly identified the presence or absence of cow's milk and by-products for all products (with the exception of cookies without cow's milk); however, the difference was only statistically significant $(p=0.005)$ for margarine without cow's milk.
The total numbers of correctly identified products in each group are summarized in Table 2 . The median number of correct choices was higher in the study group than in the control group, and the difference was statistically significant for products that contain cow's milk. The paired analysis of the number of correctly identified products in each of the groups demonstrated that the products that did contain cow's milk were more often correctly identified by both groups, with this difference having statistical significance.

The number of labels read by the members of the study group was lower than had been expected. The median (1st and 3rd quartiles in parenthesis) number of product labels that

Table 2 - Number of correctly identified products with and without cow's milk for the study and control groups

\begin{tabular}{|c|c|c|c|}
\hline Correctly identified products & $\begin{array}{l}\text { Study group } \\
\quad(n=24)\end{array}$ & $\begin{array}{l}\text { Control group } \\
(n=23)\end{array}$ & $\mathbf{p}$ \\
\hline With cow's milk & $4.0(4.0-5.0)$ & $3.0(3.0-4.0)$ & $0.005^{*}$ \\
\hline Without cow's milk & $3.0(1.0-4.0)$ & $2.0(1.0-2.5)$ & $0.079 *$ \\
\hline Total & $6.0(5.0-8.3)$ & $5.0(4.5-6.0)$ & $0.008 *$ \\
\hline
\end{tabular}

* Median, with 1st and 3rd quartiles given in parentheses, Mann-Whitney test.

Wilcoxon test: Study group = products with vs. products without cow's milk: $p=0.002$;

Control group $=$ products with vs. products without cow's milk: $p<0.001$. 
Table 3 - Relationship between interviewee reading at least one label and correctly identifying five or more of the 10 products with or without cow's milk

\begin{tabular}{lcc}
\hline & \multicolumn{2}{c}{$\begin{array}{c}\text { Number of correctly } \\
\text { identified products }\end{array}$} \\
\cline { 2 - 3 } & > 5 products & 5 5 products \\
\hline \multirow{2}{*}{ Read one or more labels } & $16(34.0 \%)$ & $4(17.4 \%)$ \\
Read no labels & $9(19.1 \%)$ & $18(38.3 \%)$ \\
Total & $25(53.2 \%)$ & $22(46.8 \%)$ \\
& & \\
\hline
\end{tabular}

Chi-square test: $p=0.004$

Odds ratio $=8.0$ (95\% confidence interval: 1.8 and 39.9$)$.

were read by the study group was $1.0(0.0-6.0)$ and in the control group this was $0.0(0.0-1.8)$. The Mann-Whitney test did not reveal a statistically significant difference $(p=0.138)$ between the two groups.

The total number of packaging labels read in each of the groups correlated with the total number of correctly identified products with and without cow's milk. A moderate correlation was observed (Pearson coefficient $=+0.578$; $\mathrm{p}<$ 0.001 ) between the total number of labels read and the number of products correctly identified as not containing cow's milk, whereas, for the products with cow's milk, a low correlation was found $(+0.175 ; \mathrm{p}=0.238)$.

Table 3 illustrates the statistically significant association between interviewees reading at least one label, irrespective of whether a member of the study or the control group, and correct identification of five or more of the 10 products. The odds ratios indicate that, when an individual read at least one label, their chances (odds ratio $=8.0$ ) of correctly identifying more than five products increased in relation to individuals who did not read any labels.

Just three $(6.4 \%)$ of the total of 47 individuals correctly identified all 10 products. All of these interviewees were the parents of children on diets excluding cow's milk and by-products, read three, seven and nine labels, and had received professional instruction on how to identify foods that are or are not permitted in a diet free from cow's milk and by-products by reading their labels. None of the members in the control group (who had not received instruction) correctly identified all of the products displayed.

\section{Discussion}

Two groups of parents were studied: the study group, made up of the parents of children on diets excluding cow's milk and by-products, and the control group, comprising parents of children who did not require any type of exclusion diet. The groups did not differ in terms of sex, age or economic classification (Table 1).
It is important to mention that few published articles have dealt with this subject. ${ }^{10,15}$ A study was carried out in New York to assess whether the parents of children with food allergies were capable of recognizing allergens in the labels of commercial food products. It was found that the parents had difficulty in recognizing the presence of allergens, especially cow's milk and soy. ${ }^{10}$ Another study, ${ }^{15}$ published in 2004, assessed members of The Food Allergy \& Anaphylaxis Network (FAAN), in the USA. The study included 489 members from Chicago, Baltimore and New York who responded to a questionnaire related to interpretation of the ingredients of food products based on the information on labels. ${ }^{15}$ They found that $16.0 \%$ of allergic reactions occurred as a result of misunderstanding of the terms used on packaging labels. ${ }^{15}$

In our study, we investigated recognition of expressions related to cow's milk. Analysis of the parents' replies as to which of the expressions they recognized showed that the common and scientific terms were recognized equally by the study and control groups and, therefore, that their recognition was not dependent on previous instruction. In contrast, the technical expressions were more frequently recognized by individuals who had received previous instruction on implementing diets free from cow's milk (study group). These technical expressions frequently appear on package labels and should also be included in the instruction given on diets free from cow's milk and by-products. It was also observed that $62.0 \%$ of the individuals who had been instructed were not given a list of expressions relating to cow's milk, especially the scientific ones, which were recognized by just $17.7 \%$ of individuals in the study group. It is worth pointing out that merely informing parents of the terms used to describe cow's milk and by-products is not alone sufficient for them to recognize which products the patient can and cannot use in their diet. In other words, it is of the utmost importance that they also acquire the habit of reading product labels. In this context, those individuals who correctly identified more than five of the 10 products had read at least one label. Along the same lines, it should be emphasized that just three individuals in the study group correctly identified all 10 products and that they read three, seven and nine labels. The importance of correctly reading labels in order to identify products with or without cow's milk is thus clearly demonstrated. This feature demonstrates that greater emphasis should be given to information on expressions related to cow's milk and by-products, considering that $62.0 \%$ of the individuals in the study group had not received this type of information.

When identifying which foods were permitted in the diet free from cow's milk and by-products and which were not, it was found that there was a tendency for the individuals, both those in the study group and those in the control group, to correctly identify products that did contain cow's milk in their composition (Table 2). This correct identification rules out the danger of contact with the allergen; however, on the other 
hand, classifying permitted foods as being prohibited makes the diet even more restrictive. Diets without cow's milk or by-products represent a risk for low intake of calcium ${ }^{7,16,17}$ and energy, ${ }^{7}$ which can compromise the child's nutritional status.

In recent years, in certain developed countries, there has been discussion of the need to change the labeling of commercial food products. ${ }^{10,11,15}$ The United States government proposed changes to labeling regulations for food products, making clarity of packaging labels and identification of ingredients with the greatest allergenic potential obligatory. Similarly, in the European Union new regulations have been implemented making it mandatory to include information on commonly allergenic ingredients on packaging, irrespective of the quantity contained. ${ }^{18}$ These precautions with food safety have gained in relevance as a result of the increases that are being observed in the prevalence rates of food allergy in many parts of the world.

In synthesis, the results of this study have allowed us to detect that, during diets free from cow's milk and by-products, foods that do contain cow's milk in their composition are identified more frequently. However, the same did not occur with foods that do not contain cow's milk. It is, therefore, important that when instruction is given on implementation of diets excluding cow's milk and by-products, emphasis should be given not just to the products that should not be consumed, but also to those which are permitted, thereby reducing the restrictive character of this type of diet.

In conclusion, the capacity of parents to correctly identify products with and without cow's milk and by-products is not completely satisfactory. Strategies should be developed to improve the effectiveness of the guidance provided on implementing diets without cow's milk and by-products.

\section{References}

1. Host A. Cow's milk protein allergy and intolerance in infancy. Some clinical, epidemiological and immunological aspects. Pediatr Allergy Immunol. 1994;5(5 Suppl): 1-36.

2. Henriksen C, Eggesbo M, Halvorsen R, Botten G. Nutrient intake among two-year-old children on cows' milk-restricted diets. Acta Paediatr. 2000;89: 272-8.

3. Vieira MC, Toporovski M, Morais MB, Spolidoro JV, Fonseca MC, Araújo GT, et al. Cow's milk allergy in children: a survey on its main features in Brazil. JPEN. 2005;29:S27.
4. Sampson HA. Food allergy. Part 1: immunopathogenesis and clinical disorders. J Allergy Clin Immunol. 1999;103(5 Pt 1):717-28.

5. Isolauri E. The treatment of cow's milk allergy. Eur J Clin Nutr. 1995;49 Suppl 1:S 49-55.

6. Morais MB, Fagundes-Neto U. Alergia alimentar ao leite de vaca. In: Morais MB, Campos SO, Silvestrini WS. Guia de medicina ambulatorial hospitalar: pediatria. São Paulo: Manole; 2005. p. 749-54.

7. Medeiros LC, Speridião PG, Sdepanian VL, Fagundes-Neto U, Morais MB. Ingestão de nutrientes e estado nutricional de crianças em dieta isenta de leite de vaca e derivados. J Pediatr (Rio J). 2004;80:363-70.

8. Mofidi S. Nutritional management of pediatric food hypersensitivity. Pediatrics. 2003;111(6 Pt 3):1645-53.

9. Bock SA, Muñoz-Furlong A, Sampson HA. Fatalities due to anaphylactic reactions to foods. J Allergy Clin Immunol. 2001;107:191-3.

10. Joshi P, Mofidi S, Sicherer SH. Interpretation of commercial food ingredient labels by parents of food-allergic children. J Allergy Clin Immunol. 2002;109: 1019-21.

11. Altschul AS, Scherrer DL, Muñoz-Furlong A, Sicherer SH. Manufacturing and labeling issues for commercial products: relevance to food allergy. J Allergy Clin Immunol. 2001;108:468.

12. Associação Brasileira de Empresas de Pesquisa (ABEP). Critério de classificação econômica Brasil. 2003. http://www.abep.org/ codigosguias/ABEP_CCEB.pdf Access: 28/08/2005.

13. SigmaStat [computer program]. Version 3.1 for Windows. San Jose (CA): Systat Software Inc.; 2002.

14. Dean AG, Dean JA, Coulombier D, Brendel KA, Smith DC, Burton $\mathrm{AH}$, et al. Epi-Info, Version 6.0: a word processor database and statistics program for epidemiology on microcomputers. Atlanta (GA): Center of Disease Control and Prevention; 1994.

15. Simons E, Weiss CC, Furlong TJ, Sicherer SH. Impact of ingredient labeling practices on food allergic consumers. Ann Allergy Asthma Immunol. 2005;95: 426-8.

16. Infante $D$, Tormo R. Risk of inadequate bone mineralization in diseases involving long-term suppression of dairy products. J Pediatr Gastroenterol Nutr. 2000;30:310-3.

17. Hidvegi E, Arato A, Cserhati E, Horvath C, Szabo A, Szabo A. Slight decrease in bone mineralization in cow milk-sensitive children. J Pediatr Gastroenteol Nutr. 2003;36:44-9.

18. Taylor SL, Hefle SL. Food allergen labeling in the USA and Europe. Curr Opin Allergy Clin Immunol. 2006;6: 186-90.

Correspondence:

Mauro Batista de Morais

Rua Pedro de Toledo, 441

CEP 04039-031 - São Paulo, SP - Brazil

E-mail: mbmorais@osite.com.br; mbmorais.dped@epm.br. 